University of San Diego

Digital USD

Fall 11-18-2020

\title{
The Challenges and Opportunities Created by a Global Pandemic's Effects on Consumer Shopping Behavior Within the Fashion Retail Industry
}

Kate O'Connor

University of San Diego

Follow this and additional works at: https://digital.sandiego.edu/honors_theses

Part of the E-Commerce Commons, Fashion Business Commons, and the Marketing Commons

\section{Digital USD Citation}

O'Connor, Kate, "The Challenges and Opportunities Created by a Global Pandemic's Effects on Consumer Shopping Behavior Within the Fashion Retail Industry" (2020). Undergraduate Honors Theses. 79.

https://digital.sandiego.edu/honors_theses/79

This Undergraduate Honors Thesis is brought to you for free and open access by the Theses and Dissertations at Digital USD. It has been accepted for inclusion in Undergraduate Honors Theses by an authorized administrator of Digital USD. For more information, please contact digital@sandiego.edu. 
The Challenges and Opportunities Created by a Global Pandemic's Effects on Consumer Shopping Behavior Within the Fashion Retail Industry

\author{
A Thesis \\ Presented to \\ The Faculty and the Honors Program \\ Of the University of San Diego
}

By

Kate Ann O'Connor

Marketing

2020 


\section{Table of Contents}

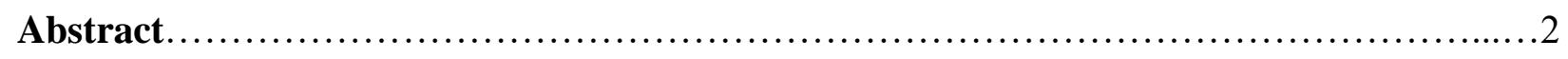

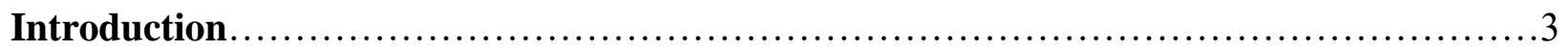

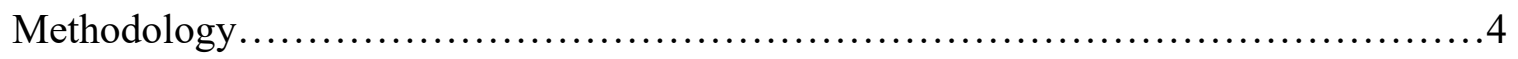

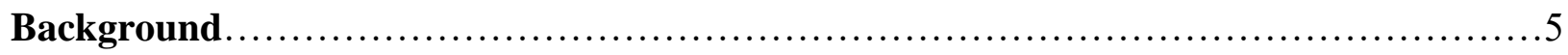

Introduction of E-commerce....................................................

Omnichannel Retailing ..................................................10

Retail Apocalypse.........................................................12

COVID-19 Situation...................................................... 15

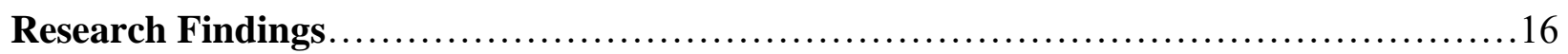

Changes in Consumer Shopping Behavior................................... 16

Challenges and Opportunities............................................19

Overall...........................................................19

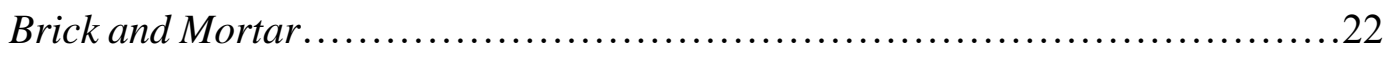

E-commerce...................................................25

Omnichannel....................................................28

Recommendations for Retailers........................................... 31

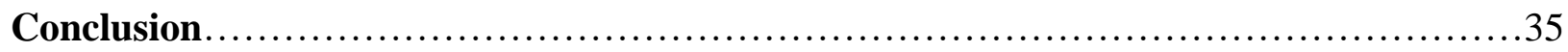

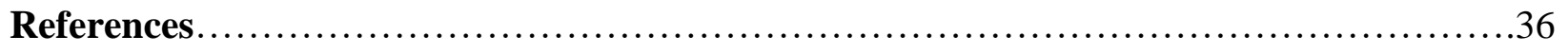




\begin{abstract}
The fashion retail industry has already been undergoing an extensive transformation since the introduction of e-commerce in the late 1990s. However, changes in consumer shopping behavior caused by the COVID-19 pandemic have fundamentally altered the industry in a matter of months. Because the COVID-19 pandemic is relatively recent, there is a lack of literature regarding the challenges and opportunities for fashion retailers in light of these changes in consumer behavior. This project will illuminate the challenges and opportunities created by the COVID-19 pandemic for the different distribution modes in the fashion retail industry: brick and mortar stores, e-commerce, and omnichannel retailing. By synthesizing existing literature on the prior e-commerce disruption, pre-pandemic situation, and the COVID-19 situation, this study will provide context to explain fashion retail industry's current state of flux. Research findings will also reveal valuable insights about consumer shopping behavior in a pandemic and the role consumers play in industry transformation. Based on these insights, this study will provide research-based recommendations for fashion retailers to thrive in the current landscape and as the industry eventually moves to a post-pandemic environment.
\end{abstract}




\section{The Challenges and Opportunities Created by a Global Pandemic's Effects on Consumer Shopping Behavior Within the Fashion Retail Industry}

The United States (US) is the largest fashion retail market in the world and was valued at $\$ 368$ billion last year (Statista, 2020a). The fashion retail industry provides jobs for 1.8 million Americans (JEC, 2019), and as of the writing of this study, there are 314,000 total brick and mortar store establishments in the country (NRF \& PWC, 2020). However, this prevalent industry is currently in a state of turmoil due to the coronavirus pandemic. Because of the pandemic's unprecedented nature, fashion retailers were vastly unprepared to respond to this disruption (Pantano et al., 2020). Iconic retailers such as Neiman Marcus, J. Crew, and Lord \& Taylor have already filed for Chapter 11 Bankruptcy since the beginning of the pandemic, and 25,000 brick and mortar stores are expected to close by the end of 2020 (Coresight Research, 2020). While COVID-19 has certainly presented new challenges for fashion retailers, the pandemic is not the only source of their struggles. The fashion retail industry had already been undergoing substantial changes due to shifts in consumer shopping behavior caused by the introduction of e-commerce (Verhoef et al., 2015). Some retailers had embraced such changes, while others were slower to adapt. The COVID-19 pandemic created another disruption in the fashion retail industry that has accelerated changes in consumer shopping behavior. The pandemic has illuminated the need for fashion retailers to adapt their business models in order to remain competitive in the industry.

This review will explore the literature that informs the understanding of the changes in consumer shopping behavior caused by COVID-19 and the challenges and opportunities presented to retailers as a result of these changes. The first section discusses the prior disruptions in the fashion retail industry, including e-commerce, omnichannel retailing, and the retail 
apocalypse. Section two focuses on the changes in consumer shopping behavior caused by the pandemic and the current challenges and opportunities presented to retailers. The final section provides recommendations for retailers to respond to these challenges and opportunities.

Together these sections will identify what the literature reveals about the impact of disruption on the fashion retail industry and the responses by consumers and retailers.

\section{Methodology}

The purpose of this paper is to address the challenges and opportunities for US fashion retailers presented by changes in consumer shopping behavior caused by the COVID-19 pandemic.

\section{Research Questions}

Four research questions guided this study:

Research Question 1: What are the changes in consumer shopping behavior caused by the COVID-19 pandemic?

Research Question 2: What are the challenges presented by these changes in consumer shopping behavior for brick and mortar, e-commerce, and omnichannel modes of distribution?

Research Question 3: What are the future opportunities for these three modes of distribution? Research Question 4: Given these changes in consumer shopping behavior, how can brick and mortar retailers thrive?

To answer these research questions, I conducted an extended literature review of scholarly sources published between 2005 and 2020. The majority of sources came from academic journals such as the Journal of Retailing, Journal of Business Research, and the Journal of Marketing. Recent data and statistics from sources such as the U.S. Census Bureau, McKinsey Insights, and Statista are also included. Additionally, I interviewed an account 
manager at the NPD Group who consults clients who are major contributors in the US fashion retail industry.

\section{Background}

\section{Introduction of E-commerce}

In Western countries including the United States, the retail store has evolved through a series of different formats, from small general stores, to department stores, to franchises, and eventually to e-commerce (McArthur et al., 2015). Throughout this industry evolution, the role of the brick and mortar store had remained central in the customer purchase process until the rise of e-commerce (Gillpatrick et al., 2019). With the exception of catalogs and home shopping networks, the brick and mortar store had been the sole destination where consumers could purchase products (Neslin et al., 2006). The brick and mortar store also served as the primary mode through which customers could have experiences that influence their perceptions of the retailer's brand (Lemon \& Verhoef, 2016).

Verhoef et al. (2015) argue, "Retailing has changed dramatically in the last two decades due to the advent of the online channel and ongoing digitization" (p. 174). The introduction of ecommerce threatened the traditional brick and mortar store's dominance in the retailing value chain (Cao \& Li, 2015; Reinartz et al., 2019). While technological advancements made the development of an e-commerce channel possible, shifting consumer behavior and heightened expectations have contributed to the industry transformation spurred by e-commerce (Reinartz et al., 2019; Rigby, 2011). Gillpatrick et al. (2019) argue that changing consumer preferences are the most important driver of retail evolution because new technologies must be accepted by consumers to be successful. Reinartz et al. (2019) propose that the introduction of e-commerce allowed for the fulfillment of long-standing customer needs, such as convenience, 
individualization, and empowerment, in new ways. Prior to the introduction of e-commerce, the brick and mortar retailer held virtually all control over the service interaction, while consumers were "relegated to an essentially passive role as price, product, and communication recipients" (Ibid, p. 352). The rise of e-commerce led to an increase in consumer power due to consumers' improved access to information and more retail options (Labrecque et al., 2013).

The development of the e-commerce channel was disruptive to brick and mortar retailers' business models (Sorescu, 2011). Consumers began to expect that retailers offer an e-commerce channel in addition to their brick and mortar channel (Gillpatrick et al., 2019). To respond to this expectation and stay competitive in the market, many traditional brick and mortar retailers introduced an e-commerce channel (Kim \& Chun, 2018). Further, many new direct-to-consumer pure players entered the market, also threatening the dominance of brick and mortar retailers (Rose et al., 2012). Pure players are retailers who do not have a brick and mortar presence but rather sell products directly to consumers through their websites.

\section{Consumer Benefits and Choice Determinants of E-commerce}

A major focus in the literature has been the benefits the e-commerce channel provides consumers. These benefits include the convenience of being able to shop from home at any time, a wider selection of available products and sizes, and access to more and better information (Avery et al., 2012; Pauwels \& Neslin, 2015; Reinartz et al., 2019). Consumers can easily compare prices across different retailers online, as well as read customer reviews and detailed product information (Verhoef et al., 2015). Additionally, with the increased use of customer data by retailers, the e-commerce channel can offer personalized recommendations to customers based on past purchases in a way that brick and mortar stores cannot (Neslin \& Shankar, 2009). 
Literature has also focused on consumers' choice determinants for shopping through the e-commerce channel versus the brick and mortar channel (Kushwaha \& Shankar 2013; Verhoef et al., 2007). It has been suggested that the e-commerce channel is more conducive to utilitarian or goal-directed shopping (Avery et al., 2012; Helm et al., 2020; Pauwels \& Neslin, 2015). Utilitarian shopping value "reflects the acquisition of products and/or information in an efficient manner and can be viewed as a more task-oriented, cognitive, and non-emotional outcome of shopping" (Jones et al., 2006, p. 974). The increased convenience and access to product information the e-commerce channel provides enables utilitarian shoppers to make efficient and informed purchase decisions. The same research suggested that brick and mortar stores may be more capable of providing hedonic shopping value, which refers to the "value received from multisensory, fantasy, and emotive aspects of a shopping experience" (Ibid, p. 974). The social and experiential aspects of brick and mortar stores offer hedonic shoppers value that is independent from the shopping task itself. Previous research has proposed the online channel caters to a different segment of customers than brick and mortar stores, and thus customers can be clearly segmented based on their channel preference (Neslin et al., 2006). However, more recent research has suggested that customers' goals for different shopping experiences vary, and therefore whether they choose to shop in-store or online also varies (Helm et al., 2020). While a customer may rely on e-commerce for repeat purchases, the same customer may value the experience of shopping in a brick and mortar store at other times.

The main disadvantages of the e-commerce channel in comparison to the brick and mortar channel are having to wait for the product to arrive and not being able to touch or try on a product prior to purchase (Avery et al., 2012). In recent years retailers have made strides in combating such disadvantages. Retailers continue to offer faster shipping speeds and improve the 
user interfaces of their online channels to give customers a better idea of how a product will look on (Dzyabura et al., 2019; Sorescu et al., 2011).

\section{Impact of E-commerce on Retailers}

The introduction of e-commerce also offered benefits to retailers. Neslin et. al (2006) propose an "availability effect," which suggests that adding more channels is a form of increasing distribution (p. 101). By offering more channels through which customers can purchase products, increased distribution lowers search costs for customers and thus increases a retailer's total sales (Pauwels \& Neslin, 2015). With the addition of an e-commerce channel, retailers could broaden their reach to more potential customers, including those in geographic markets where they do not have brick and mortar stores (Dzyabura et al., 2019). Additionally, having an e-commerce channel could help build brand awareness in geographic markets where retailers want to open brick and mortar stores (Avery et al., 2012). With access to more customer data from the e-commerce channel, retailers could personalize their marketing efforts to different consumers based on where they are in the purchase process (Shi et al., 2020).

The addition of an e-commerce channel also created some disadvantages for traditional brick and mortar fashion retailers. First, the decision of a retailer to add an e-commerce channel to its existing brick and mortar channel required a high level of investment (Dzyabura et al., 2019). Retailers had to make decisions regarding how to allocate resources across their increased number of channels. E-commerce margins are typically worse than those of the brick and mortar channel due to high customer acquisition costs and fulfillment expenses (Mintel, 2019).

Additionally, while ease of market entry could be both a benefit and disadvantage, the entry of new pure players created more competition for traditional brick and mortar retailers (Helm et al., 2020). Pure players evaded the traditional brick and mortar mode of distribution and 
implemented a direct-to-consumer business model to sell products to customers through their websites.

The development of the e-commerce channel also gave rise to the consumer behaviors of showrooming and webrooming. Showrooming refers to the practice of a consumer gathering information about a product in a brick and mortar store and then purchasing the product online (Gensler et al., 2017). Webrooming is the opposite behavior and occurs when consumers gather information about a product online but make the final purchase in a brick and mortar store (Verhoef et al., 2007). Showrooming and webrooming are most harmful to retailers who are not the sole distributors of their product offerings, such as department stores. Consumers may exhibit "free-riding behavior" by gathering information about a product in one retailer's store and then making the final purchase from another retailer's e-commerce website, or vice versa (Basak et al., 2017, p. 36). It has been shown that consumers will make the final purchase in a way that maximizes their utilities; for example, if the consumer found the product online at another retailer for a better price, they would be inclined to purchase the product from that retailer (Ibid). In turn, this retailer also free rides on the sales efforts of the initial retailer by getting the customer's final sale.

On a related note, e-commerce led to a decline in customer loyalty to retailers, because the online channel offered consumers lower switching costs between retailers and access to an increased number of options (Rezabakhsh et al., 2006). Again, this would not apply as much to fashion retailers who are the sole distributors of their products, but it could apply to department stores that sell a variety of different brands. If a consumer found a product at another retailer at a better price, they may be inclined to make the purchase from that retailer instead. 


\section{Omnichannel Retailing}

The introduction of the e-commerce channel led to a new phenomenon called multichannel retailing. Multichannel retailing refers to the practice of offering customers information, goods, services, and support through multiple channels (Rangaswamy \& Van Bruggen, 2005). A channel is defined as "a customer contact point, or a medium through which the firm and customer interact" (Neslin et al., 2006, p. 96). An increase in the number of available channels came with decisions for retailers about whether to add new channels to their existing business models (Verhoef et al., 2015). At the time, these channels included the traditional brick and mortar store, an e-commerce channel, home shopping networks, and the direct marketing channel of the catalog (Neslin et al., 2006). Under multichannel retailing strategies, different channels were usually managed separately within firms, and their strategies and objectives were not integrated (Verhoef et. al, 2015).

In more recent years, the concept of multichannel retailing has evolved into omnichannel retailing (Shi et al., 2020; Verhoef et. al, 2015; Zhang et al., 2018). Verhoef et al. (2015) first highlighted this shift in the introduction to the Journal of Retailing's Special Issue on MultiChannel Retailing, which was published in 2015. Omnichannel management is defined as "the synergetic management of the numerous available channels and customer touchpoints, in such a way that the customer experience across channels and the performance over channels is optimized" (Verhoef et al., 2015, p. 176). The main difference from multichannel retailing is omnichannel retailing's increased focus on providing a seamless customer experience across channels by employing cross-channel integration (Cai \& Lo, 2020). Cross-channel integration refers to "the degree to which a firm coordinates the objectives, design, and deployment of its channels to create synergies for the firm and offer particular benefits for customers" (Cao \& Li, 
2015). Whereas channels were frequently managed separately under multichannel retailing strategies, cross-channel integration is an essential aspect of an omnichannel strategy (Ibid). The consumer benefits of cross-channel integration include the ability to gather information in convenient ways, reduced confusion, and the freedom to use different channels in different situations (Ibid). Synergies created for the firm include increased customer loyalty, higher sales conversion rates, and more opportunities for cross-selling between different channels (Ibid). Through cross-channel integration, "different channels become blurred as the natural borders between channels begin to disappear" (Verhoef et al., 2015, p. 175).

The rise of omnichannel retailing can be attributed to the addition of more potential channels and customer touchpoints to the retailing mix (Verhoef et. al, 2015). In the new phase of omnichannel retailing, the channel scope was much larger than with multichannel retailing. New mobile channels included apps, social media platforms, and any touchpoints through which the customer interacts with the retailer or even other customers. The addition of more digital and mobile channels to the retailing mix was acknowledged as another disruptive change in the retail industry (Rigby, 2011). As in the case with the development of e-commerce, consumer expectations played a role in the shift to omnichannel retailing (Ibid). The development of omnichannel strategies by retailers satisfied customers' needs for constant connection and a more streamlined shopping experience (Gillpatrick et al., 2019). Omnichannel retailing provides even more empowerment for consumers by offering them more choices of how to shop and gather information (Patten et al., 2020). In the omnichannel phase, customers predominantly use multiple channels in the search and purchase process (Ibid). The ability to use multiple channels in the shopping process, and to be able to do so seamlessly and simultaneously, became expected by many customers (Helm et al., 2020). Therefore, an omnichannel strategy became a 
requirement for retailers to stay competitive in this era of increased digitization (Rezaei \& Valaei, 2017). For retailers, the rise of omnichannel retailing came with decisions such as which new channels to implement, to what degree to coordinate channels, and how to manage omnichannel shoppers (Avery et al., 2012; Cao \& Li, 2015; Verhoef et al., 2007). Retailers were motivated to implement omnichannel strategies because omnichannel shoppers have a higher lifetime value compared to single-channel shoppers (Kushwaha \& Shankar, 2013).

It should be noted that in recent literature both the terms multichannel and omnichannel have been used to describe the concept of omnichannel retailing. For the purposes of this project, the term omnichannel will be used.

\section{Retail Apocalypse}

The retail apocalypse refers to the large number of closures of brick and mortar retail stores starting in 2010 (Loeb, 2020). The term was first used in mainstream media (Biron, 2019; Danziger, 2017; Townsend et al., 2017), but the phenomenon has been widely covered in academic literature as well (Berman, 2019; Childs et al., 2020; Helm et al., 2020). In both academic literature and mainstream media, the cause of the retail apocalypse and its implications for the fashion retail industry have been heavily debated. Nevertheless, scholars agree that the fashion retail industry has been undergoing massive transformation spurred by increased digitization (Alexander \& Blazquez Cano, 2020; Grewal et al., 2017; Sorescu, 2011). A total of 9,300 brick and mortar store closings were announced in the US in 2019, making it the largest year for store closings thus far (Coresight Research, as cited by Keyes, 2019).

\section{Contributing Factors}

Retailers decide to close certain brick and mortar store locations to avoid the cost of operating unprofitable stores or to avoid sales cannibalization of nearby stores or other channels 
(Feng \& Fay, 2020). In mainstream media, the retail apocalypse is often attributed to the rise of e-commerce (Bhattarai, 2019; Townsend at al., 2017). Brick and mortar stores did have to compete for sales with the new online channel, and e-commerce had been growing at a 4:1 rate compared to the overall retail industry (Mintel, 2020). However, by 2019, e-commerce only accounted for $11 \%$ of total sales, meaning that the majority of retail sales were still occurring in brick and mortar stores (Statista, 2020b).

Research has found that consumers view themselves as playing a role in this transformation as well, and they cite their preference for e-commerce over brick and mortar shopping as an explanation for brick and mortar retail's decline (Helm, 2020). Interestingly, while consumers believed their behavior contributed to the decline of brick and mortar retail, they did not express that their behavior could avert the situation (Ibid).

An alternative theory that has been presented to explain the retail apocalypse is that the US is heavily over-retailed (Berman, 2019). In 2018, the US had 23.5 square feet of retail space per person, which is more than any other country in the world and significantly more than the following highest rates in Canada and Australia of 16.8 square feet and 11.2 square feet, respectively (Statista, 2020d). Berman suggested that the US simply had too many brick and mortar retail stores to begin with, which has led to store closures during the retail apocalypse.

Department stores, which account for $30 \%$ of total US mall square footage (Green Street, 2020, as cited by Maheshwari, 2020), have suffered during the retail apocalypse in particular (Helm, 2020). Reinartz et al. (2017) proposed that the "one-stop shopping approach" that is a crucial part of department stores' value proposition may actually be better suited to e-commerce platforms (p. 361). This one-stop shopping approach refers to customers' tendency to seek out multiple items across different product categories and brands when shopping at a department 
store. Reinartz et al. (2017) suggested that the search and convenience capabilities of the ecommerce channel may better support this type of shopping. Another way that e-commerce threatened department stores' dominance was by giving brands typically carried by department stores the ability to distribute their products directly through their own online channels (Ibid). Department stores have traditionally served as anchor stores for malls, meaning they attract consumers to visit the mall and help drive foot traffic to surrounding stores (Simona Damian et al., 2011). It has been proposed that department stores' troubles have contributed to the retail apocalypse because when a mall's anchor stores close, the remaining stores suffer from reduced consumer foot traffic (Berman, 2019).

\section{Counter Arguments}

While store closures have mainly been depicted as problematic signs for retailers, Feng and Fay (2020) propose that store closures could simply be a sign that a retailer is managing its resources effectively and has chosen to reallocate resources to a different area of its business. Therefore, they caution against the mindset that store closures are always a troubling sign and recommend retailers approach their store expansion and contraction strategies on a case-by-case basis.

Another interesting recent trend was the decision of many direct-to-consumer brands, who were previously e-commerce pure players, to open brick and mortar retail stores (Hagberg et al., 2017). Brands including Warby Parker, Everlane, and Bonobos have added a brick and mortar mode of distribution to their original e-commerce channel (Flint, 2020). Such decisions support the idea that having a brick and mortar store is valuable in promoting brand awareness and providing unique relationship-building opportunities with customers (Avery et al., 2012).

\section{Responses in Literature}


In academic literature at the time, there emerged an increased focus on the experience offered by brick and mortar stores. While customers looked to e-commerce for convenience in the era of omnichannel retailing, the brick and mortar store remained a key touchpoint for offering unique customer experiences (Verhoef et al., 2009). Sachdeva and Goel (2015) proposed that success in retail was increasingly becoming less about what a retailer sells and rather how they sell it, leading to a "new experiential paradigm shift in shopping" (p. 292). This shift led to the rise of experiential retail. The goal of experiential retail is to engage the customer by creating emotional bonds between a retailer and the customer that go beyond the purchase (Alexander \& Blazquez Cano, 2020; Sorescu, 2011). Scholars proposed methods for brick and mortar retailers to provide new forms of customer value through a unique in-store experience. These methods included alternate store formats such as pop-up shops and fashion trucks (Childs et al., 2020) and in-store technologies such as augmented reality and virtual assistants (Grewal et al., 2020; Hoyer et al., 2020).

\section{COVID-19 Situation}

Prior to the pandemic, the US economy had been experiencing a record 128 months of economic expansion that peaked in February 2020 (National Bureau of Economic Research, 2020). However, the fashion retail industry was already predicted to suffer in 2020 , with McKinsey forecasting a three to four percent decline in growth of the global fashion industry compared to 2019 (McKinsey, 2020).

The first signs of the COVID-19 disruption in the US fashion retail industry came from overseas (McMaster et al., 2020). Global fashion corporations are subject to risks such as late deliveries, long lead times, and stock-outs or overstock (Ibid). Many US fashion retailers rely on factories in China and other countries that had already begun coronavirus-related lockdowns in 
January and February. These lockdowns caused inventory shipments to US retailers to be delayed (Ibid). US fashion retailers became concerned with how they would get inventory from overseas, and when they did eventually get it, whether they would even need it anymore (Aleksander, 2020).

On March 11, 2020, the World Health Organization declared the coronavirus disease a pandemic. Two days later, US President Donald Trump declared a national emergency due to the coronavirus outbreak in the US. State governors across the country implemented shelter-in-place orders, requiring non-essential businesses to close and urging citizens to stay home unless performing essential activities. The scope and duration of shelter-in-place orders varied by state, but almost all non-essential brick and mortar retailers were required to shut down for some period of time. These orders sent brick and mortar fashion retailers into a panic, many of whom were already struggling prior to the pandemic (McIntosh, 2020). The impact on the US fashion retail industry was immediate, with clothing and accessories sales experiencing a $50.7 \%$ yearover-year decline in the month of March (U.S. Census Bureau, 2020). Since then, many major US fashion retailers, including Neiman Marcus, J. Crew, and JCPenney, have filed for Chapter 11 bankruptcy (Ilchi, 2020a). Many other fashion retailers have announced plans to permanently close some of their brick and mortar stores by the end of 2020 (Ettinger \& McDowell, 2020). The pandemic has caused several changes in consumer shopping behavior in the fashion retail industry that retailers must navigate.

\section{Research Findings}

\section{Changes in Consumer Shopping Behavior}

This section will address Research Question 1, which was "What are the changes in consumer shopping behavior caused by the COVID-19 pandemic?" As a consequence of a 
pandemic, consumers are shopping in ways that deviate from their typical shopping habits, both in the fashion retail industry and in other categories (Pantano et al., 2020; Sheth, 2020; Zwanka \& Buff, 2020). Literature has made some comparisons to consumer behavior in past times of crisis, but it is difficult to draw any complete parallels to another event due to the pandemic's unprecedented nature (Pantano et al., 2020). Four major changes in consumer shopping behavior have emerged.

\section{Panic buying}

The first shift in consumer behavior was the panic buying of essential goods such as toilet paper and pasta, often in large quantities (Kirk \& Rifkin, 2020; Pantano et al., 2020; Sheth, 2020). Pantano et al. (2020) have attributed this behavior to the "scarcity effect," which refers to a perceived scarcity of products in times of crisis (p. 210). Kirk and Rifkin (2020) attribute the hoarding of goods in large quantities to an effort by consumers to regain control and avoid being caught unprepared. Hoarding is a common reaction to uncertainty surrounding the future supply of essential goods (Sheth, 2020). The tendency of consumers to hoard products was likely exacerbated by supply chain disruptions that resulted in product stockouts because when the threat of scarcity is high, consumers are motivated to restore control by hoarding (Kirk \& Rifkin, 2020).

\section{Shift to e-commerce shopping}

During the pandemic, the combination of limited accessibility to stores and consumers' increased health concerns created the need for alternative channels of distribution (Pantano et al., 2020). Many consumers shifted to shopping through e-commerce, including some who had never shopped online before (Ibid). During lockdowns, consumers shopped online for certain categories, such as fashion retail, simply out of necessity because stores were closed (Sheth, 
2020). Consumers also used e-commerce to purchase essential products that they had not previously bought online, such as groceries (Pantano et al., 2020). 48\% of respondents to a Mintel survey reported shopping more online due to the pandemic (Mintel, 2020). In March, the number of US online grocery delivery and pickup customers rose to 39.5 million people, a $146 \%$ increase from 16.1 million customers in August 2019 (Statista, 2020c). As consumers have become increasingly comfortable with online shopping and discovered its benefits, it is predicted that many consumers will continue these shopping habits post-pandemic (McKinsey, 2020; Pantano et al., 2020).

\section{Heightened safety concerns}

Consumers have new safety concerns regarding a wide variety of activities, including dining at restaurants, seeing friends and family, and shopping in brick and mortar stores. According to a September survey of US consumers by McKinsey, 55\% of consumers reported feeling somewhat worried about shopping in-store for non-necessities (McKinsey, 2020). Safety concerns have contributed to consumers' preference for online shopping during the pandemic (Pantano et al., 2020). Further, they may lead consumers to evaluate an in-store shopping experience based on new criteria in the future, such as cleanliness and whether social distancing procedures were enforced (Roggeveen \& Sethuraman, 2020).

\section{More conscientious in purchase decisions}

Finally, consumers have become more conscientious shoppers during the pandemic. During times of crisis, consumers increasingly look for ways to justify their purchase decisions (Erketin et al., 2020). It has been found that consumers' price consciousness is more susceptible to changes than other traits in times of crisis (Steenkeep \& Maydeu-Olivares, 2015). This is reflected in current data as over half of consumers report paying more attention to prices and 
increasingly looking for ways to save money during the pandemic (McKinsey, 2020). Consumers also report spending less on discretionary items such as clothing and continue to prioritize spending on essential goods (Ibid).

Consumers are not only looking for better prices during the pandemic, but they are also paying more attention to the actions of brands (Kirk \& Rifkin, 2020). According to a McKinsey survey of US consumers, $23 \%$ of consumers report paying increased attention to how a company treats its employees, and 17\% report paying more attention to retailers' sustainability solutions (McKinsey, 2020). The responses by fashion retailers to the coronavirus will play a role in customers' decisions to support those brands during and after the pandemic (Kirk \& Rifkin, 2020).

\section{Challenges and Opportunities}

This section will address Research Questions 2 and 3, which were "What are the challenges presented by these changes in consumer shopping behavior for brick and mortar, ecommerce, and omnichannel modes of distribution?" and "What are the future opportunities for these three modes of distribution?" Two overall challenges and opportunities for the fashion retail industry have emerged, as well as two distinct challenges and opportunities for each mode of distribution. Some of these challenges are brand new as a result of the pandemic, and others are existing challenges that have been aggravated by the pandemic.

\section{Overall Challenges}

Economic recession. According to the National Bureau of Economic Research, as of June 8th, 2020, the US economy is officially in a recession due to the coronavirus. This recession is distinct from past recessions, such as the Great Recession of 2008, in terms of the speed and source of the economic collapse (Leonhardt, 2020). As previously mentioned, the US was 
experiencing a record 128 months of economic growth prior to the COVID-19 outbreak (National Bureau of Economic Research, 2020). Because of the rapid lockdowns imposed, the employment rate quickly rose to a record high of $14.3 \%$ in April, surpassing the Great Recession of 2008's peak of 10\% unemployment (U.S. Bureau of Labor Statistics, 2020). Furthermore, while past economic recessions have been financially driven, the current recession was caused primarily by health and safety concerns and can therefore be considered consumer driven (Deshpandé et al., 2020).

Fashion retail is particularly impacted by the recession due to its nature as a discretionary spending category (McKinsey \& BOF, 2020). Discretionary spending categories such as fashion retail are among the first items consumers will reduce spending on during a recession. This is reflected in current data as $40 \%$ of consumers report currently spending less on apparel than they normally would (McKinsey, 2020). Consistent with behavior from the start of the pandemic, consumers continue to prioritize spending on essential goods over discretionary items (Pantano et al., 2020).

Economists have proposed a theory of a K-shaped economic recovery (Van Brussel, 2020; Ahktar, 2020). This theory suggests that certain sectors of the economy, such as technology and software, are recovering quickly, while businesses in the service industry, including brick and mortar fashion retail, are recovering more slowly or even still continuing to decline. It has been predicted that fashion retail will not return to pre-pandemic levels of growth until 2023 (Mintel, 2020).

Stay-at-home orders. While many non-essential businesses have reopened (with new restrictions and capacity guidelines), the CDC still encourages people to stay home as much as possible to mitigate the spread of COVID-19. In industries where it is possible to work from 
home, companies have yet to reopen offices and employees remain working from home. Many companies do not yet have planned dates of return to the office (Friedman \& Browning, 2020).

Consumers typically exhibit buy-now-wear-now behavior when shopping for fashion apparel, meaning they buy clothes to satisfy an immediate need, such as for an upcoming event or a seasonal weather change (Schambach, 2016). As many fashion retailers have sped up their production cycles in recent years, consumers have become increasingly accustomed to this behavior (Petro, 2018). With indefinite stay-at-home orders in place, consumers' need to purchase new clothing was significantly reduced (Callahan, 2020). Consumer demand decreased drastically in certain categories, such as workwear. Sales of workwear have experienced $40 \%$ year-over-year decline during the pandemic, and Brooks Brothers and Men's Warehouse have already filed for bankruptcy (Edited, 2020).

\section{Overall Opportunities}

Ability to pivot quickly. Many fashion retailers responded quickly to the pandemic and the changes in consumer shopping behavior it caused, especially those that already had ecommerce and omnichannel strategies in place. When brick and mortar stores were forced to shut down, retailers shifted their focus to improving their e-commerce channels and home delivery services (Pantano et al., 2020). Many retailers also added a curbside pickup option to their buy-online-and-pick-up-in-store services (Briedis et al., 2020). By June 2020, 34\% of the fashion retailers in Digital Commerce 360's Top 1,000 list offered curbside pickup, which was up significantly from only 1.6\% of retailers in January 2020 (Digital Ecommerce 360, 2020).

Fashion retailers began offering new products such as face masks and more comfortable clothing that would be suitable for wearing at home (Brydges \& Hanlon, 2020). Designers such as Gucci even provided medical masks and protective garments for frontline health workers, and 
Bulgari produced hand sanitizer to donate to hospitals (Pantano et al., 2020). Once legally able to, fashion retailers reopened their brick and mortar stores with heightened safety procedures in place, such as temperature checks, social distancing, and contactless payment methods (Testa \& Paton, 2020).

Consumers are still shopping. Although overall apparel sales experienced a decline during the pandemic, consumers did not stop shopping altogether. As consumers settled into their stay-at-home routines, sales increased in certain apparel categories, including loungewear, activewear, and basics categories (NPD Group, 2020, as cited by Callahan, 2020). US sales of activewear experienced 40\% year-over-year growth in April (Edited, 2020).

Additionally, with brick and mortar stores closed, consumers quickly transitioned to ecommerce shopping. In Q2 of 2020, e-commerce sales experienced 45\% year-over-year growth (U.S. Census Bureau, 2020).

Once non-essential businesses were allowed to reopen, in some states brick and mortar fashion retail stores reopened with foot traffic close to $50 \%$ of pre-pandemic levels, which was considered high given the circumstances (Klara, 2020). This eager return could potentially be explained by the theory of pent-up demand. This theory suggests that because consumers were denied access to brick and mortar stores for a period of time, pent-up demand created a temporary sharp increase in foot traffic once consumer access was restored (Sheth, 2020).

\section{Brick and Mortar Retail Challenges}

Susceptible to lockdowns. Fashion retailers' brick and mortar stores are susceptible to lockdowns due to their nature as non-essential businesses. While the US has not imposed a second wave of lockdowns during the pandemic, many European countries have, forcing nonessential brick and mortar stores to close once again (Buckley \& Spurrell, 2020). Store 
lockdowns this spring had a detrimental impact on US fashion retailers, and many are still attempting to recover from the lost revenues during that period (Callahan, 2020). Even the growth of e-commerce shopping was not enough to sustain fashion retailers' business operations. According to the NPD Group, fashion retailers only recovered one third of sales lost from store lockdowns through e-commerce (as cited by Callahan, 2020). These store lockdowns can explain why the impact of the coronavirus has been more detrimental than the past Great Recession. Even though retail sales suffered in 2008 , brick and mortar stores were still allowed to be open (Ibid). Store lockdowns also took a toll on malls who rely on fashion retailers as the majority of their tenants. According to an NRF survey (2020), less than a third of retail store mall tenants were able to pay their rent in June.

Threatens benefits of brick and mortar shopping experience. Even as brick and mortar stores have reopened, the typical brick and mortar store experience has fundamentally changed, with new requirements such as temperature checks, masks, and social distancing imposed (Yohn, 2020). These new safety procedures threaten the advantages that the brick and mortar channel typically offers consumers. One of the advantages the brick and mortar channel typically offers consumers is the ability to touch and try on products prior to purchasing (Avery et al., 2012). According to a July survey by retail analytics company First Insight, 68\% of female customers feel unsafe trying on apparel during the pandemic (2020). Most brick and mortar retailers continue to offer this benefit, but they have also had to put new policies in place surrounding this behavior. For example, as part of Nordstrom's reopening procedures, the company announced that any merchandise that has been tried on by a customer will not be put back on the sales floor for 72 hours (Testa \& Paton, 2020). Heightened safety procedures such as these are costly to retailers (McKinsey, 2020). 


\section{Brick and Mortar Retail Opportunities}

Hedonic value of shopping experience. Past literature has identified two main consumer motivations for shopping: utilitarian and hedonic motives. As previously mentioned, utilitarian shopping value is more task-oriented and refers to the efficient acquisition of products or information in the shopping environment, whereas hedonic shopping value refers to the emotional, social, and sensory value garnered from a shopping experience alone (Jones et al. 2006). It has been found that consumers who prefer online shopping take a utilitarian approach to shopping, and therefore they see online shopping as an equal substitute for brick and mortar stores (Helm et al., 2020). On the other hand, consumers who are advocates of brick and mortar stores value the hedonic aspect of shopping. They view shopping as an important part of their lives and look to brick and mortar stores to provide fun, interactive, and social experiences that cannot be replicated by e-commerce (Ibid). Based on these findings, while utilitarian shoppers may continue shopping online post-pandemic, hedonic shoppers may return to stores.

As the pandemic continues, another potential opportunity for brick and mortar stores is that in-store shopping is one of the few normal social activities that is allowed right now (Amaro, 2020). Many restrictions remain on travel, dining at restaurants and bars, and even returning to work in non-essential offices. Most brick and mortar retail stores have reopened, and in-store shopping could provide a welcome escape to consumers who are looking to get out of the house and do something somewhat normal. Just as there is a segment of consumers that continued to maintain their preference for shopping in brick and mortar stores despite the developments of ecommerce and omnichannel retailing (De Keyser et al., 2015), it is predicted that there will still be a segment of consumers who prefer shopping in-store during and after the pandemic (Mintel, 2020). 
Reimagining of the brick and mortar store concept. As previously mentioned, for the past several years there has been a focus in academic literature on what the future of the brick and mortar store will look like. As consumers increasingly turn to e-commerce for benefits such as convenience and speed, scholars and industry experts have considered how brick and mortar stores can provide consumers unique experiences (Alexander \& Blazquez Cano, 2020; Grewal et al., 2017; Rigby, 2011). While COVID-19 safety precautions complicate the experiential aspect of brick and mortar stores, there are still opportunities for retailers to offer consumers valuable experiences currently and after the pandemic. Childs et al. (2020) propose non-traditional fashion marketplaces, such as pop-up stores, as a way for retailers to provide a novel and engaging experience to customers. During the pandemic, brands such as Dior and Todd Snyder opened pop-ups to connect with customers (Chitrakorn, 2020). Pop-ups remain viable during the pandemic because they are low-budget, short-term, and flexible, offering retailers a way to engage with customers in a chosen area without having to commit to a long-term retail lease (Belanger, 2020). When possible, retailers could host pop-up stores or events outdoors to help customers feel safer, as the CDC suggests the risk of the coronavirus is lower outdoors. More possibilities for the future of the brick and mortar store concept will be discussed in the Recommendations section of this paper.

\section{E-commerce Challenges}

Scalability. While retailers who already offered an e-commerce distribution mode were at an advantage, the shift to relying on e-commerce to fulfill the majority of transactions was not completely seamless. E-commerce had been previously growing at a steady rate of one to two percentage points per year (Statista, 2020b), which allowed for retailers to gradually scale their e-commerce operations. With the closure of brick and mortar stores during lockdowns, retailers 
and consumers shifted to relying on the e-commerce channel to complete the majority of their transactions. Most retailers' e-commerce channels were not designed to fulfill this increased amount of transactions (Pantano et al., 2020). Additionally, retailers had to decide how to navigate social distancing guidelines with employees in factories and implement new procedures to ensure safe deliveries of merchandise to customers. These factors caused supply chain disruptions in the form of delayed or cancelled orders (Ivanov, 2020; McMaster, 2020).

Costly to retailers. Implementing and managing an e-commerce channel requires large capital investments (Neslin et al., 2006). Retailers must hire and train employees to perform new roles, which can be expensive (Tagashira \& Minami, 2019). Shipping capabilities must also be improved so distribution centers are equipped to fulfill individual customer orders (Ibid). In the context of an omnichannel strategy, retailers must determine how to coordinate the activities of this new channel with existing channels, which also comes with costs (Neslin et al., 2006).

While many retailers' e-commerce channels have experienced major sales growth during the pandemic, this does not always translate into higher profits (Thomas \& Repko, 2020). Ecommerce margins are typically worse than brick and mortar margins due to high customer acquisition costs and fulfillment expenses (Mintel, 2019). Additionally, product return rates are highest through the e-commerce channel because consumers cannot try on products prior to purchase and typically order multiple sizes (Dzyabura et al., 2019). For every returned product, retailers incur shipping, processing, and refurbishing expenses (Ibid).

The majority of sales will continue to take place in a brick and mortar store following the pandemic (Mintel, 2020). Given this, it is difficult for retailers to decide whether to invest heavily in e-commerce if growth is only temporary. 


\section{E-commerce Opportunities}

Growth as percentage of sales. As previously mentioned, prior to the pandemic only $11 \%$ of purchases took place through e-commerce. During the pandemic, e-commerce experienced major growth as a percentage of sales, and e-commerce now accounts for $16 \%$ of all sales (U.S. Census Bureau, 2020).

Before the pandemic, the brick and mortar channel was still the dominant focus for many retailers. But growth in e-commerce during COVID-19 has motivated several retailers, such as Zara, to invest more heavily in their online channel. In June, Zara owner Inditex announced plans to permanently close 1,200 of its brick and mortar stores to reallocate resources to its online channel (Chaudhari, 2020). While store closures are often portrayed as a problematic sign for retailers, they also have the ability to be profitable when retailers make strategic decisions to reallocate resources (Feng \& Fay, 2020). Given the impact of the pandemic on consumer shopping behavior, investing more heavily in the e-commerce channel could be a beneficial opportunity for retailers.

Increased consumer comfort with online shopping. Past research has segmented consumers based on whether they prefer to shop online or in-store (Neslin et al., 2006). However, almost ten years ago Avery et al. (2012) acknowledged that the demographic differences between e-commerce shoppers and brick and mortar shoppers were beginning to disappear as e-commerce shopping became more mainstream. During the pandemic, the distinctions between brick and mortar store shoppers and e-commerce shoppers have become increasingly blurred, along with their reasons for selecting one channel over another. During the period of store lockdowns, consumers had no choice but to shop online for categories such as fashion retail (Sheth, 2020). 48\% percent of consumers report shopping more online during the 
pandemic (Mintel, 2020). Research suggests that consumers will continue these behaviors in the future, which will give retailers the opportunity to attract more shoppers to their e-commerce channels, rather than only a certain segment of consumers. As many consumers remain concerned about in-store shopping, e-commerce provides a favorable alternate method of shopping that can be done from home.

\section{Omnichannel Challenges}

Difficult to implement and manage. Omnichannel management has been a major focus in past literature (Verhoef et al., 2015; Zhang et al., 2018; Cai \& Lo, 2020), and the pandemic has proven how essential a successful omnichannel strategy is for retailers (Briedis et al., 2020). While many retailers already had omnichannel strategies in place prior to the pandemic, not all did, especially smaller boutique retailers. Other retailers acted quickly to offer new omnichannel services, such as buy-online-and-pick-up-in-store, to customers during the pandemic.

An omnichannel strategy requires large investments by retailers, which is often a barrier to implementation (Bethan \& Blazquez Cano, 2020). Additionally, because introducing an omnichannel strategy requires a retailer to modify its competitive strategy, retailers face several challenges during implementation. Such challenges include the inability to create an integrated supply chain across multiple channels and misaligned attitudes toward the transformation within the company (Ye et al., 2018). Once implemented, omnichannel strategies continue to be difficult to manage because they rely on a high level of cross-channel integration within the firm (Patten et al., 2020).

Currently, many fashion retailers are focused on simply avoiding bankruptcy during the pandemic. While omnichannel strategies have proven necessary, it may be difficult for retailers to commit the resources necessary to implement these strategies at this time. 
Providing a unified experience. The goal of an omnichannel strategy is to provide a seamless overall experience for the customer, but this has been particularly hard for retailers to offer during this time of uncertainty (Pantano et al., 2020). Brick and mortar stores had to navigate enforcing new safety procedures for the first time, and the e-commerce channel experienced issues such as slow order deliveries due to supply disruptions.

In addition, $\mathrm{CDC}$ and government communications were changing rapidly, and most state lockdown orders were extended beyond their initial expiration dates. It was difficult for retailers to provide clear communication to customers when they were unsure about when they would be allowed to reopen and in what capacity (McNeish, 2020). This was especially a challenge for larger retailers who have multiple brick and mortar locations across the US or the world because guidelines by each state and country varied. As consumers have become more conscientious shoppers during the pandemic, brick and mortar retailers need to continue to strive to provide customers with consistent and transparent communication across all channels.

\section{Omnichannel Opportunities}

Buy-online-and-pick-up-in-store. Buy-online-and-pick-up-in-store (BOPIS) is a type of omnichannel retailing service that offers customers the option to order an item through the online channel and pick up the item at a retailer's brick and mortar store. The impact of BOPIS services has been widely examined in literature (Gao \& Su, 2017; Jin et al., 2018; Lin et al., 2020). BOPIS offers consumers many benefits, such as saving on shipping costs, the convenience of an easier shopping experience, and the instant gratification of having their items waiting for them at the store when they arrive (Gao \& Su, 2017). BOPIS services also offer benefits to retailers, such as the benefit of increased store sales through cross-selling, which occurs when consumers make an additional purchase when they come into the store to collect their BOPIS order (Ibid). 
During the COVID-19 pandemic, BOPIS services have become increasingly important and widely used by consumers. According to Adobe Analytics, August 2020 sales using BOPIS experienced $259 \%$ year-over-year growth (2020, as cited by Chen, 2020b). $69 \%$ of consumers report that they will continue to use BOPIS in the long term (McKinsey, 2020). As previously mentioned, many retailers also began offering curbside pickup options during the pandemic (Briedis et al., 2020). Gao and Su (2017) previously cautioned that introducing curbside pickup services can decrease the cross-selling benefit, but in 2020 such services are more of a necessity. As consumers remain hesitant about shopping in-store, BOPIS and curbside pickup will continue to be valuable services that retailers can offer to meet customers' needs.

Providing a digital brand experience. Retailers who already had e-commerce and omnichannel strategies in place were able to rely on these channels to fulfill customer orders during lockdowns. However, retailers went beyond simply fulfilling customer orders. As previously stated, an omnichannel strategy focuses on offering a superior customer experience, rather than solely completing the purchase transaction. Increased forms of digital technology, such as social media and apps, have created opportunities for retailers to stay connected to consumers virtually (Kaatz, 2020; van Heerde et al., 2020). Retailers found new and creative ways to engage customers virtually, especially during the early weeks of the pandemic when stores were closed. lululemon hosted free workout classes via Instagram Live, Everlane offered customers virtual styling appointments over Zoom, and Nordstrom hosted virtual cooking classes on Instagram. Fashion designers even gave consumers a glimpse into the usually highly exclusive Fall New York Fashion Week, which was also held virtually this year. Designers such as Rebecca Minkoff used Instagram to present their new collections via livestream (Ilchi, 
2020b). As restrictions remain on in-person experiences and events, retailers can continue to rely on virtual experiences to engage customers.

\section{Recommendations for Retailers}

This section will address Research Question 4, which was "Given these changes in consumer shopping behavior, how can brick and mortar retailers thrive?” Lockdowns and heightened safety concerns have called into question the future viability of brick and mortar stores. Despite the challenges the pandemic has created for brick and mortar stores, most fashion retailers are continuing to pursue a brick and mortar mode of distribution. The following recommendations will enable brick and mortar retailers to thrive in the current landscape and a post-pandemic environment. They will also prepare retailers to handle another catastrophic event in the future.

\section{Rethink supply chain agility and distribution methods}

The need for retailers to rethink agility in their supply chains has been identified by several scholars (McMaster et al., 2020; Pantano et al., 2020; Sheth, 2020). During the pandemic, rigid supply chains left retailers unable to respond quickly to rapid changes in consumer demand (McMaster et al., 2020). Luxury brands and retailers offering workwear were left with an excessive amount of inventory, while some retailers selling loungewear and activewear could not produce enough to keep up with increased demand (Ibid). The fashion industry has always been characterized by high demand volatility and low predictability, which often leads to an overstocking or shortage of inventory (Mehrjoo \& Pasek, 2016). This need for agility in the fashion retail industry is not new, but the supply chain disruptions created by the pandemic made this need more pressing. 
Increased supply chain agility would allow retailers to shorten the lead times between changes in consumer demand and their responses to those changes (Pantano et al., 2020). Increasing agility will require increased collaboration and communication with all members of the supply chain (Ibid). With shorter lead times, retailers could restock products throughout the season in response to customer demand instead of placing large orders in advance based on predicted demand (McMaster et al., 2020).

McMaster et al. (2020) also suggest that retailers may want to diversify the geographic location of their suppliers. During the pandemic, retailers with suppliers concentrated in a single geographic area were at higher risk of supply chain disruptions, especially if those geographic areas were heavily affected by coronavirus outbreaks. By having suppliers in several locations, retailers will be better prepared for global disruptions such as pandemics in the future (Ibid).

Another proposed course of action is using brick and mortar stores as distribution centers, which some fashion retailers already do in a certain capacity with BOPIS services (Chen, 2020b). This strategy became increasingly popular in other industries during the pandemic. Whole Foods temporarily closed a handful of their New York brick and mortar store locations and used them as distribution centers to fulfill increased online orders (Stern, 2020). This decision also presents an alternate use for brick and mortar stores during potential future lockdowns.

As McMaster et al. (2020) indicate, building agility is expensive for retailers, and it may be not wise for retailers to completely rebuild their supply chains or distribution methods in response to an extremely rare event such as the pandemic. Retailers will need to make strategic decisions based on their company's unique capabilities and resources. 


\section{Implement a strong omnichannel strategy}

Prior to the pandemic, literature had already identified a strong omnichannel strategy as a necessity for retailers in this era of digitization (Cao and Li, 2015; Reinartz et al., 2019). During the pandemic, it became clear that retailers cannot rely on their brick and mortar operations alone. Those retailers who already had strong e-commerce and omnichannel strategies in place prior to the pandemic were better equipped to handle the coronavirus lockdowns (Pantano et al., 2020). A strong omnichannel strategy remains necessary to combat the threat of future brick and mortar store lockdowns. It also provides a way for retailers to remain connected to those consumers who are not ready to return to in-store shopping.

As consumers have become increasingly reliant on digital channels during the pandemic, their expectations surrounding those experiences have also become higher (Yohn, 2020). Retailers need to offer consumers omnichannel services that will streamline their shopping experiences. Such services include the option to consult with sales associates online, personalized messaging via email and text message, and accurate information about available inventory at store locations (Chen, 2020a). Retailers should also continue to improve their BOPIS services and offer curbside pickup options (Ibid).

Finally, if they had not before, retailers need to integrate the management of their different channels within their companies in order to provide customers with a consistent brand experience (Shi et al., 2020) Integrating channels can lead to benefits for retailers such as increased sales and customer retention (Cao \& Li, 2015).

\section{Focus on the in-store experience}

In the process of implementing a strong omnichannel strategy, retailers cannot lose focus on the brick and mortar store experience. Despite the massive transformation in the fashion 
industry created by increased digitization, up until the pandemic, consumers' in-store experiences were largely determined by the same factors as they were ten years ago (Bäckström \& Johansson, 2017). Now more than ever, the need for retailers to rethink the future of the brick and mortar store experience is recognized (Machtiger, 2020; Chen, 2020a; Yohn, 2020). While this was already a focus in academic literature prior to the pandemic, retailers must now reimagine this experience with a heightened focus on safety. Research indicates that consumers will continue to be concerned about safety even after the pandemic (McKinsey, 2020), so retailers need to continue to acknowledge these concerns and communicate that customers' health and wellbeing are a priority (Pantano et al., 2020). Safety procedures such as increased sanitization and social distancing will remain crucial in brick and mortar stores (Yohn, 2020). Given increased consumer preference for e-commerce shopping during the pandemic, brick and mortar retailers will need to offer consumers a compelling reason to visit a brick and mortar store. Compelling reasons could include new types of shopping experiences and in-store technology.

Machtiger (2020) proposes a new type of shopping experience in which the brick and mortar store acts as a stage or showroom. Rather than having store shelves lined with an abundance of merchandise, the store would be set up like a showroom with products prominently displayed on mannequins. If consumers were interested in purchasing a product, a sales associate would collect it for them from the back of the store and assist them in completing the purchase transaction. Treating the brick and mortar store as a showroom could help alleviate consumer anxieties involved with touching and trying on clothes during the pandemic. Machtiger also suggests that retailers offer consumers the ability to book their shopping experience ahead of time, reducing the risk of crowds or having to wait in line outside the store. 
As previously mentioned, in-store technology was already a focus prior to the pandemic (Alexander \& Blazquez Cano, 2020; Hoyer et al., 2020; Grewal et al., 2017), and industry experts propose it will become increasingly important in the context of the pandemic (Chen, 2020a; Lieber, 2020). In-store technologies include smart mirrors and dressing rooms powered by augmented reality that would allow customers to try out products without having to physically put them on (Hoyer et al., 2020). Brands such as Levi's, Kohl's, and Kendra Scott have already introduced augmented reality enabled technology during the pandemic (Papagiannis, 2020). Such in-store technologies could aid in mitigating customer safety concerns. They would also help to create a successful omnichannel experience by blending distinctions between the brick and mortar store and digital channels.

\section{Conclusion}

Fashion retailers were vastly unprepared to handle the COVID-19 pandemic and the resulting shifts in consumer shopping behavior. It is imperative that fashion retailers act now to respond to such changes in consumer shopping behavior and prepare themselves for future industry disruptions. The pandemic is far from over, and many of the shifts in consumer behavior will remain even after the pandemic. If fashion retailers are adaptable and implement researchbacked recommendations, they have the ability to thrive in the current landscape and a postpandemic environment. If retailers do not adapt, more bankruptcies will be inevitable. 


\section{References}

Ahktar, A. (2020, September 30). Meet the 'K-shaped recession.' Business Insider. https://www.businessinsider.com/what-is-a-k-shaped-recovery-coronavirus-pandemic

Aleksander, I. (2020, August 6). Sweatpants forever. The New York Times Magazine. https://www.nytimes.com/interactive/2020/08/06/magazine/fashion-sweatpants.html

Alexander, B., \& Blazquez Cano, M. (2020). Store of the future: Towards a (re)invention and (re)imagination of physical store space in an omnichannel context. Journal of Retailing and Consumer Services 55. https://doi.org/10.1016/j.jretconser.2019.101913

Amaro, S. (2020, July 27). How the pandemic is changing the way we shop - and what we're buying. CNBC. https://www.cnbc.com/2020/07/27/the-future-of-retail-amid-covid19.html

Avery, J., Steenburgh, T. J., Deighton, J., \& Caravella, M. (2012). Adding bricks to clicks: Predicting the patterns of cross-channel elasticities over time. Journal of Marketing 76(3), 96-111. https://doi.org/10.1509/jm.09.0081

Bäckström, K., \& Johansson, U. (2017). An exploration of consumers' experiences in physical stores: comparing consumers' and retailers' perspectives in past and present time. The International Review of Retail, Distribution, and Consumer Research 27(3), 241-259. https://doi.org/10.1080/09593969.2017.1314865

Basak, S., Basu, P., Avittathur, B., \& Sikdar, S. (2017). A game theoretic analysis of multichannel retail in the context of "showrooming". Decision Support Systems 103, 3445. https://doi.org/10.1016/j.dss.2017.09.002

Belanger, L. (2020, June 25). Pop-up retail was made for the pandemic. Fortune. https://fortune.com/2020/06/25/coronavirus-pop-up-retail-short-term/ 
Berman, B. (2019). Flatlined: Combatting the death of retail stores. Business Horizons 62(1), 7582. https://doi.org/10.1016/j.bushor.2018.08.006

Bethan, A., \& Blazquez Cano, M. (2020). Store of the future: Towards a (re)invention and (re)imagination of physical store space in an omnichannel context. Journal of Retailing and Consumer Services 55. https://doi.org/10.1016/j.jretconser.2019.101913.

Bhattarai, A. (2019, April 10). 'Retail apocalypse' now: Analysts say more than 75,000 stores could be doomed. The Washington Post. https://www.washingtonpost.com/business/2019/04/10/retail-apocalypse-now-analystssay-more-us-stores-could-be-doomed/

Biron, B. (2019, December 23). The last decade was devastating for the retail industry. Here's how the retail apocalypse played out. Business Insider. https://www.businessinsider.com/retail-apocalypse-last-decade-timeline-2019-12

Briedis, H., Kronschnabl, A., Rodriguez, A., \& Ungerman, K. (2020, May 14). Adapting to the next normal in retail: The customer experience imperative. McKinsey Insights. https://www.mckinsey.com/industries/retail/our-insights/adapting-to-the-next-normal-inretail-the-customer-experience-imperative

Brydges, T., \& Hanlon, M. (2020). Garment worker rights and the fashion industry's response to COVID-19. Dialogues in Human Geography 10(2), 195-198. https://doi.org/10.1177/2043820620933851

Buckley, J., \& Spurrell, M. (2020, October 30). The latest on lockdowns throughout Europe. Condé Nast Traveler. https://www.cntraveler.com/story/how-countries-in-europe-arereopening 
Cai, Y., \& Lo, C. K. (2020). Omni-channel management in the new retailing era: A systematic review and future research agenda. International Journal of Production Economics, 229. https://doi.org/10.1016/j.ijpe.2020.107729

Callahan, C. (2020, April 30). How coronavirus could alter the way we shop for clothes from now on. Today. https://www.today.com/style/how-coronavirus-could-alter-way-we-shopclothes-now-t180039

Cao, L., \& Li, L. (2015). The impact of cross-channel integration on retailers' sales growth. Journal of Retailing, 91(2), 198-216. https://doi.org/10.1016/j.jretai.2014.12.005

Chaudhari, S. (2020, June 10). Zara owner to close 1,200 stores as it outlines post-coronavirus future. The Wall Street Journal. https://www.wsj.com/articles/zara-to-close-1-200-storesas-it-outlines-post-coronavirus-future-11591794618

Chen, C. (2020a, September 22). 6 ways the pandemic has changed how people shop. Business of Fashion. https://www.businessoffashion.com/articles/retail/pandemic-shopping-habits

Chen, C. (2020b, October 5). 5 tech tools that should be on every fashion executive's radar. Business of Fashion. https://www.businessoffashion.com/articles/technology/5-techtools-that-should-be-on-every-fashion-executives-radar

Childs, M., Blanchflower, T., Hur, S., \& Matthews, D. (2019). Non-traditional marketplaces in the retail apocalypse: Investigating consumers' buying behaviors. International Journal of Retail and Distribution Management 4(3), 262-286. https://doi.org/10.1108/IJRDM03-2019-0079

Chitrakorn, K. (2020, August 23). Pop-up power: Why short-term stores are set to thrive. Vogue Business. https://www.voguebusiness.com/consumers/pop-up-power-why-short-termstores-are-set-to-thrive 
Coresight Research (2020, June 9). 25,000 stores are predicted to close in 2020, as the coronavirus pandemic accelerates industry upheaval. https://coresight.com/press/25000stores-are-predicted-to-close-in-2020-as-the-coronavirus-pandemic-accelerates-industryupheaval/

Danziger, P. N. (2017, July 13). Retail apocalypse: A look at what comes next and it isn't pretty. Forbes. https://www.forbes.com/sites/pamdanziger/2017/07/13/retail-apocalypse-whatcomes-next/?sh=2716754d23d4

Digital Ecommerce 360. (2020, July 17). Apparel retailers launch curbside pickup en masse. https://www.digitalcommerce360.com/2020/07/17/apparel-retailers-launch-curbsidepickup-en-masse/

De Keyser, A., \& Scheper, J. (2015). Multichannel customer segmentation: Does the after-sales channel matter? A replication and extension. International Journal of Research in Marketing 32(4), 453-456.

Deshpandé, R., Mintz, O., \& Currim, I. S. (2020, June 16). Your customers have changed. Here's how to engage them again. Harvard Business School Working Knowledge. https://hbswk.hbs.edu/item/your-customers-have-changed-here-s-how-to-engage-themagain

Dzyabura, D., El Kihal, S., Hauser, J. R., \& Ibragimov, M. (2019). Leveraging the power of images in managing product return rates. http://dx.doi.org/10.2139/ssrn.3209307

Edited. (2020, April 9). How home workouts are boosting the activewear market during COVID19. Edited. https://edited.com/resources/activewear-market-and-covid-19/

Edited. (2020, August 17). Has COVID erased the demand for workwear? No, but it does look different. Edited. https://edited.com/resources/workwear-market/ 
Erketin, Z. O., Oflac, B. S., \& Serbetcioglu, C. (2020). Fashion consumption during economic crisis: Emerging practices and feelings of consumers. Journal of Global Fashion Marketing. https://doi.org/10.1080/20932685.2020.1754269

Ettinger, Z., \& McDowell, E. (2020, October 23). 26 clothing stores you'll see less of in the future. Business Insider. https://www.businessinsider.com/clothing-brands-stores-youllsee-less-of-in-the-future-2020-7

Feng, C., \& Fay, S. (2020). Stores closings and retailer profitability: A contingency perspective. Journal of Retailing 96(3), 411-433. https://doi.org/10.1016/j.jretai.2020.01.002

First Insight, Inc. (2020, May 11). Shoppers ready to buy apparel but don't feel safe trying it on as stores reopen. https://www.firstinsight.com/press-releases/shoppers-ready-to-buyapparel-but-dont-feel-safe-trying-it-on-as-stores-reopen

Flint, J. M. (2019, October 28). Brick-and-mortar stores are making a comeback. Harvard Business School Working Knowledge. https://hbswk.hbs.edu/item/brick-and-mortarstores-are-making-a-comeback

Friedman, G., \& Browning, K. (2020, October 13). July is the New January: More companies delay return to office. The New York Times. https://www.nytimes.com/2020/10/13/technology/offices-reopening-delaycoronavirus.html

Gao, F., \& Su, X. (2017) Omnichannel retail operations with buy-online-and-pick-up-in-store. Management Science 63(8): 2478-2492. https://doi.org/10.1287/mnsc.2016.2473

Gensler, S., Neslin, S. A., \& Verhoef, P. C. (2017). The showrooming phenomenon: It's about more than just price. Journal of Interactive Marketing 38, 29-43. https://doi.org/10.1016/j.intmar.2017.01.003 
Gillpatrick, T., Blunck, E., \& Boga, S. (2019). Understanding the role of consumer behavior in forecasting the impact of Industry 4.0 and the wave of digital disruption driving innovation in retailing. Dubrovnik International Economic Meeting 4(1), 165-176. https://hrcak.srce.hr/228708

Grewal, D., Noble, S. M., Roggeveen, A. L., \& Nordfalt, J. (2020). The future of in-store technology. Journal of the Academy of Marketing Science 48, 96-113. https://doi.org/10.1007/s11747-019-00697-z

Grewal, D., Roggeveen, A. L., \& Nordfalt, J. (2017). The future of retailing. Journal of Retailing 93(1), 1-6. https://doi.org/10.1016/j.jretai.2016.12.008

Hagberg, J., Jonsson, A., \& Egels-Zanden, N. (2017). Retail digitalization: Implications for physical stores. Journal of Retailing and Consumer Services 39, 264-269. http://dx.doi.org/10.1016/j.jretconser.2017.08.005

Helm, S., Hyun Kim, S., \& Van Riper, S. (2020). Navigating the 'retail apocalypse': A framework of consumer evaluations of the new landscape. Journal of Retailing and Consumer Sciences 54. https://doi.org/10.1016/j.jretconser.2018.09.015

Hoyer, W. D., Kroschke, M., Schmitt, B., Kraume, K., \& Shankar, V. (2020). Transforming the customer experience through new technologies. Journal of Interactive Marketing 51, 5771. https://doi.org/10.1016/j.intmar.2020.04.001

Ilchi, L. (2020a, August 6). All the major fashion brands and retailers severely impacted by the COVID-19 pandemic. WWD. https://wwd.com/fashion-news/fashion-scoops/coronavirusimpact-fashion-retail-bankruptcies-1203693347/ 
Ilchi, L. (2020b, September 10). New York Fashion Week is going virtual, here's how to tune in. WWD. https://wwd.com/fashion-news/fashion-scoops/new-york-fashion-week-spring2021-free-virtual-events-fashion-shows-1234579411/

Ivanov, D. (2020). Predicting the impacts of epidemic outbreaks on global supply chains: A simulation-based analysis on the coronavirus outbreak (COVID-19/SARS-CoV-2) case. Transportation Research Part E 136. https://doi.org/10.1016/j.tre.2020.101922

Jin, M., Li, G., \& Cheng, T. C. (2018). Buy online and pick up in-store: Design of the service area. European Journal of Operational Research 268(2), 613-623. https://doi.org/10.1016/j.ejor.2018.02.002

Jones, M. A., Reynolds, K. E., \& Arnold, M. J. (2009). Hedonic and utilitarian shopping value: Investigating differential effects on retail outcomes. Journal of Business Research 59(9), 974-981. https://doi.org/10.1016/j.jbusres.2006.03.006

Kaatz, C. (2020). Retail in my pocket - replicating and extending the construct of service quality into the mobile commerce context. Journal of Retailing and Consumer Services 53, https://doi.org/10.1016/j.jretconser.2019.101983

Keyes, D. (2020, January 6). A new high of over 9,300 stores closed in the US in 2019, almost double the number that closed in 2018. Business Insider. https://www.businessinsider.com/store-closures-reached-new-high-in-2019-2020-1

Kim, J., \& Chun, S. (2018). Cannibalization and competition effects on a manufacturer's retail channel strategies: Implications on an omni-channel business model. Decision Support Systems 109, 5-14. https://doi.org/10.1016/j.dss.2018.01.007 
Kirk, C. P., \& Rifkin, L. S. (2020). I'll trade you diamonds for toilet paper: Consumer reacting, coping and adapting behaviors in the COVID-19 pandemic. Journal of Business Research 117, 124-131. https://doi.org/10.1016/j.jbusres.2020.05.028

Klara, R. (2020, June 9). Some states already see retail foot traffic at nearly $50 \%$ of normal after reopening. AdWeek. https://www.adweek.com/retail/retail-foot-traffic-returning-statesreopening-shopping-data/

Kushwaha, T., \& Shankar, V. (2013). Are multichannel customers really more valuable? The moderating role of product category characteristics. Journal of Marketing 77(4), 67-85. https://doi.org/10.1509/jm.11.0297

Labrecque, L., vor dam Esche, J., Mathwick, C., Novak, T. P., \& Hofacker, C. F. (2013). Consumer power: Evolution in the digital age. Journal of Interactive Marketing 27(4), 257-269. https://doi.org/10.1016/j.intmar.2013.09.002

Lemon, K. N., \& Verhoef, P. C. (2009). Understanding customer experience throughout the customer journey. Journal of Marketing 80(6), 69-96. https://doi.org/10.1509/jm.15.0420

Leonhardt, M. (2020, June 9). The U.S. is 'officially' in a recession - but economists say it's far from a typical downturn. CNBC. https://www.cnbc.com/2020/06/09/us-officially-in-arecession-but-its-different-than-2008.html

Lieber, C. (2020, March 2019). The fashion-tech tools getting a boost as COVID-19 takes hold. Business of Fashion. https://www.businessoffashion.com/articles/technology/the-fashiontech-companies-getting-a-boost-as-covid-19-takes-hold

Lin, X., Zhou, Y., \& Hou, R. (2020). Impact of a "buy-online-pic-up-in-store" channel on price and quality decisions in a supply chain. European Journal of Operational Research. https://doi.org/10.1016/j.ejor.2020.03.064. 
Loeb, W. (2020, July 6). More than 14,500 stores are closing in 2020 so far - a number that will surely rise. Forbes. https://www.forbes.com/sites/walterloeb/2020/07/06/9274-stores-areclosing-in-2020--its-the-pandemic-and-high-debt--more-will-close/?sh=5adeb30f729f

Machtiger, K. (2020, June 16). What will the retail experience of the future look like? Harvard Business Review. https://hbr.org/2020/06/what-will-the-retail-experience-of-the-futurelook-like

Maheshwari, S. (2020, July 5). With department stores disappearing, malls could be next. The New York Times. https://www.nytimes.com/2020/07/05/business/coronavirus-mallsdepartment-stores-bankruptcy.html

McArthur, E., Weaven, S., \& Dant, R. (2016). The evolution of retailing: A meta review of the literature. Journal of Macromarketing 36(3), 272-286. https://doi.org/10.1177/0276146715602529

McIntosh, S. (2020, April 29). Coronavirus: Why the fashion industry faces an 'existential crisis.’ BBC News. https://www.bbc.com/news/entertainment-arts-52394504

McKinsey Insights \& Business of Fashion. (2020). The state of fashion 2020 coronavirus update. https://www.mckinsey.com/industries/retail/our-insights/its-time-to-rewire-the-fashionsystem-state-of-fashion-coronavirus-update

McKinsey Insights. (2020, October 20). Survey: US consumer sentiment during the coronavirus crisis. https://www.mckinsey.com/business-functions/marketing-and-sales/ourinsights/survey-us-consumer-sentiment-during-the-coronavirus-crisis

McMaster, M., Nettleton, C., Tom, C., Xu, B., Cao, C., \& Qiao, P. (2020). Risk management: rethinking fashion supply chain management for multinational corporations in light of the 
COVID-19 outbreak. Journal of Risk and Financial Management 13(8). https://doi.org/10.3390/jrfm13080173

McNeish, J. E. (2020). Retail signage during the COVID-19 pandemic. Interdisciplinary Journal of Signage and Wayfinding 4(2), 67-89. https://doi.org/10.15763/issn.24709670.2020.v4.i2.a64

Mehrjoo, M., \& Pasek, Z. J. (2016). Risk assessment for the supply chain of fast fashion apparel industry: A system dynamics framework. International Journal of Production Research 54(1), 28-48. https://doi.org/10.1080/00207543.2014.997405

Mintel. (2019, May). Omnichannel retailing. https://reports-mintelcom.sandiego.idm.oclc.org/display/920302/?fromSearch=\%3Ffreetext\%3Domnichannel $\% 2520$ retailing\#

Mintel. (2020, June). The impact of COVID-19 on retail and ecommerce. https://reports-mintelcom.sandiego.idm.oclc.org/display/1016344/?fromSearch=\%3Ffreetext\%3Dimpact\%252 0of\%2520covid-19\%2520on\%2520retail

National Bureau of Economic Research. (2020, June 8). US Business Cycle Expansions and Contractions. https://www.nber.org/research/data/us-business-cycle-expansions-andcontractions

Neslin, S. A., Grewal, D., Leghorn, R., Shankar, V., Teerling, M. L., Thomas, J. S., \& Verhoef, P. C. (2006). Challenges and opportunities in multichannel customer management. Journal of Service Research 9(2), 95-112. https://doi.org/10.1177/1094670506293559

Neslin, S. A., \& Shankar, V. (2009). Key issues in multichannel customer management: Current knowledge and future directions. Journal of Interactive Marketing 23(1), 70-81. https://doi.org/10.1016/j.intmar.2008.10.005 
NRF \& PWC. (2020, May). The economic impact of the U.S. retail industry. https://nrf.com/retails-impact

NRF. (2020, September 24). Landlords and retail tenants compromise to emerge stronger postCOVID-19, says NRF and PJ SOLOMON. https://nrf.com/media-center/pressreleases/landlords-and-retail-tenants-compromise-emerge-stronger-post-covid-19

Pantano, E., Pizzi, G., Scarpi, D., \& Dennis, C. (2020). Competing during a pandemic? Retailers' ups and downs during the COVID-19 outbreak. Journal of Business Research 116, 209213. https://doi.org/10.1016/j.jbusres.2020.05.036

Papagiannis, H. (2020, October 7). How AR is redefining retail in the pandemic. Harvard Business Review. https://hbr.org/2020/10/how-ar-is-redefining-retail-in-the-pandemic

Pauwels, K., \& Neslin, S. A. (2015). Building with bricks and mortar: The revenue impact of opening physical stores in a multichannel environment. Journal of Retailing, 91(2), 182197. https://doi.org/10.1016/j.jretai.2015.02.001

Patten, E., Ozuem, W., Howell, K., \& Lancaster, G. (2020). Minding the competition: The drivers for multichannel service quality in fashion retailing. Journal of Retailing and Consumer Services 53. https://doi.org/10.1016/j.jretconser.2019.101974

Petro, G. (2018, January 31). How 'see-now-buy-now' is rewiring retai. Forbes. https://www.forbes.com/sites/gregpetro/2018/01/31/how-see-now-buy-now-is-rewiringretail/?sh=1a7cb1552c0b

Rangaswarmy, A., \& Van Bruggen, G. H. (2005). Opportunities and challenges in multichannel marketing: An introduction to the special issue. Journal of Interactive Marketing 19(2), 5-11. https://doi.org/10.1002/dir.20037 
Reinartz, W., Wiegand, N., \& Imschloss, M. (2019). The impact of digital transformation on the retailing value chain. International Journal of Research in Marketing 36, 350-366. https://doi.org/10.1016/j.ijresmar.2018.12.002

Rezabakhsh, B., Bornemann, D., Hansen, U., \& Schrader, U. (2006). Consumer power: A comparison of the old economy and the internet economy. Journal of Consumer Policy 29(1), 3-36. https://doi.org/10.1007/s10603-005-3307-7

Rezaei, S., \& Valaei, N. (2017). Branding in a multichannel retail environment: Online stores vs app stores and the effect of product type. Information Technology \& People 30(1), 853886. https://doi.org/10.1108/ITP-12-2015-0308

Rigby, D. K. (2011, December). The future of shopping. Harvard Business Review, 1-12. https://hbr.org/2011/12/the-future-of-shopping

Roggeveen, A. L., \& Sethuraman, R. (2020). How the COVID-19 pandemic may change the world of retailing. Journal of Retailing 96(2), 169-171. https://doi.org/10.1016/j.jretai.2020.04.002

Rose, S., Clark, M., Samouel, P., \& Hair, N. (2012). Online customer experience in e-retailing: An empirical model of antecedents and outcomes. Journal of Retailing 88(2), 308-322. https://doi.org/10.1016/j.jretai.2012.03.001

Sachadeva, I., \& Goel, S. (2015). Retail store environment and customer experience: A paradigm. Journal of Fashion Marketing and Management 19(3), 290-298. https://doi.org/10.1108/JFMM-03-2015-0021

Schambach, S. (2016, April 27). Think tank: Buy-now-wear-now - a new approach to fashion. WWD. https://wwd.com/business-news/retail/think-tank-buy-now-wear-now-fashionstephan-schambach-10418286/ 
Simona Damian, D., Dias Curto, J., \& Castro Pinto, J. (2011). The impact of anchor stores on the performance of shopping centres: The case of Sonae Sierra. International Journal of Retail \& Distribution Management 39(6), 456-475. https://doi.org/10.1108/09590551111137994

Sheth, J. (2020). Impact of Covid-19 on consumer behavior: Will the old habits return or die? Journal of Business Research 117, 280-283. https://doi.org/10.1016/j.jbusres.2020.05.059

Shi, S., Wang, Y., Chen, X., \& Zhang, Q. (2020). Conceptualization of omnichannel customer experience and its impact on shopping intention: A mixed-method approach. International Journal of Information Management 50, 325-336. https://doi.org/10.1016/j.ijinfomgt.2019.09.001

Sorescu, A., Frambach, R. T., Singh, J., Rangaswamy, A., \& Bridges, C. (2011). Innovations in retail business models. Journal of Retailing 87S(1), S3-S16. https://doi.org/10.1016/j.jretai.2011.04.005

Srinivasan, R., Sridhar, S., Narayanan, S., \& Sihi, D. (2013). Effects of opening and closing stores on chain retailer performance. Journal of Retailing 89(2), 126-139. https://doi.org/10.1016/j.jretai.2012.12.001

Statista. (2020a, May 4). Value of the U.S., China, and Western Europe apparel and footwear markets in 2019. Statista. https://www.statista.com/statistics/995215/apparel-andfootwear-market-size-by-selected-market/

Statista. (2020b, August 25). Share of e-commerce sales in total U.S. retail sales 2010-2020. https://www.statista.com/statistics/187439/share-of-e-commerce-sales-in-total-us-retailsales-in-2010/ 
Statista. (2020c, September 17). Number of customers of grocery delivery and pickup in the United States in August 2019 and March to August 2020. https://www.statista.com/statistics/1120249/coronavirus-grocery-delivery-pickupcustomers-us/

Statista. (2020, November 6). Retail space per capita in selected countries worldwide in 2018. https://www.statista.com/statistics/1058852/retail-space-per-capita-selected-countriesworldwide/

Steenkeep, J., \& Maydeu-Olivares, A. (2015). Stability and change in consumer traits: Evidence from a 12-year longitudinal study, 2002-2013. Journal of Marketing Research 52(3), 287-308. https://doi.org/10.1509/jmr.13.0592

Stern, M. (2020, September 8). With new Whole Foods facility, Amazon commits to dark stores. Forbes. https://www.forbes.com/sites/retailwire/2020/09/08/with-new-whole-foodsamazon-commits-to-dark-stores/?sh=414cafce 4928

Tagashira, T., \& Minami, C. (2019). The effect of cross-channel integration on cost efficiency. Journal of Interactive Marketing 47, 68-83. https://doi.org/10.1016/j.intmar.2019.03.002

Testa, J., \& Paton, E. (2020, May 11). Will shopping ever be the same? The New York Times. https://www.nytimes.com/2020/05/11/style/shopping-will-shopping-ever-be-thesame.html

Thomas, L., \& Repko, M. (2020, May 18). 'There's no other option:' Costco, Gap, and other retailers sweeten online offerings, but it's coming at a cost. $C N B C$. https://www.cnbc.com/2020/05/18/retailers-are-rushing-to-get-online-but-that-bringsnew-challenges.html 
Townsend, M., Surane, J., Orr, E., \& Cannon, C. (2017, November 8). America's 'retail apocalypse' is really just beginning. Bloomberg. https://www.bloomberg.com/graphics/2017-retail-debt/

U.S. Bureau of Labor Statistics (2020). Labor Statistics from the Current Population Survey.

U.S. Census Bureau. (2020). Monthly Retail Trade Survey Historical Data.

U.S. Census Bureau. (2020, August 18). Quarterly retail e-commerce sales $2^{\text {nd }}$ quarter 2020. https://www.census.gov/retail/mrts/www/data/pdf/ec_current.pdf

United States Congress JEC (2019, February 22). The economic impact of the fashion industry. https://www.jec.senate.gov/public/index.cfm/democrats/2019/2/the-economic-impact-ofthe-fashion-industry

Van Brussel, J. (2020, October 31). America's V-shaped vs. K-shaped economic recovery: What does it all mean? CNET. https://www.cnet.com/personal-finance/americas-v-shaped-vs-kshaped-economic-recovery-what-does-it-all-mean/

Van Heerde, H. J., Dinner, I. M., \& Neslin, S. A. (2020). Engaging the unengaged customer: The value of a retailer mobile app. International Journal of Research in Marketing 36(3), 420-438. https://doi.org/10.1016/j.ijresmar.2019.03.003

Verhoef, P. C., Neslin, S. A., \& Vroomen, B. (2007). Multichannel customer management: understanding the research-shopper phenomenon. International Journal of Research in Marketing 24(2), 129-148. https://doi.org/10.1016/j.ijresmar.2006.11.002

Verhoef, P. C., Kannan, P. K., \& Inman, J. J. (2015). From multi-channel retailing to omnichannel retailing: Introduction to the special issue on multi-channel retailing. Journal of Retailing 91(2), 174-181. https://doi.org/10.1016/j.jretai.2015.02.005 
Ye, Y., Lau, K. H., \& Teo, L. K. (2018). Drivers and barriers of omni-channel retailing in China. International Journal of Retail \& Distribution Management 46(7), 657-689. https://doi.org/10.1108/IJRDM-04-2017-0062

Yohn, D. L. (2020, July 6). The pandemic is rewriting the rules of retail. Harvard Business Review. https://hbr.org/2020/07/the-pandemic-is-rewriting-the-rules-of-retail

Zhang, M., Ren, C., Wang, A. G., \& He, Z. (2018). The impact of channel integration on consumer responses in omni-channel retailing: The mediating effect of consumer empowerment. Electric Commerce Research and Applications 28, 181-193. https://doi.org/10.1016/j.elerap.2018.02.002

Zwanka, R. J., \& Buff, C. (2020). COVID-19 generation: A conceptual framework of the consumer behavioral shifts to be caused by the COVID-19 pandemic. Journal of International Consumer Marketing. https://doi.org/10.1080/08961530.2020.1771646 